\title{
Impact of Enteromorpha intestinalis mats on near- bed currents and sediment dynamics: flume studies
}

\author{
C. Romano ${ }^{1,2}$, J. Widdows ${ }^{1, *}$, M. D. Brinsley ${ }^{1}$, F. J. Staff ${ }^{1}$ \\ ${ }^{1}$ Plymouth Marine Laboratory, Prospect Place, West Hoe, Plymouth PL1 3DH, United Kingdom \\ ${ }^{2}$ Present address: Marine Biology and Sea Resource Research Group, Animal Biology Department, University of Palermo, \\ Via Archirafi 18, 90123 Palermo, Italy
}

\begin{abstract}
The influence of the macroalgal mats of Enteromorpha intestinalis on near-bed current velocities and sediment dynamics was quantified by placing relatively undisturbed cored sediments in annular flumes. Density-dependent relationships were established for E. intestinalis densities; these ranged from 10 to $60 \%$ cover when air-exposed (biomass of 4 to $40 \mathrm{~g}$ ash-free dry wt $\mathrm{m}^{-2}$ ) and in comparison with bare sediment ( $0 \%$ cover). There was a significant increase in friction drag with increasing E. intestinalis biomass and percent cover, ranging from a mean $18 \%$ reduction in current velocities at $10 \%$ cover to $56 \%$ reduction at $60 \%$ cover. The net result of a reduction in currents (depth-averaged between 1 to $12 \mathrm{~cm}$ above the bed) and the physical protection of the bed by Enteromorpha was a marked reduction in sediment erosion of $60 \%$ at $10 \%$ cover to $90 \%$ at $60 \%$ cover. The presence of $E$. intestinalis also significantly enhanced sediment deposition measured as a flux from the water column to the bed. At $60 \%$ cover the deposition rate was $48 \%$ higher than on bare sediment during the first 30 min of slack water $\left(<0.05 \mathrm{~m} \mathrm{~s}^{-1}\right)$. The results show that $E$. intestinalis has a marked influence on water flow over the bed and the flux of particulate material across the sediment-water interface.
\end{abstract}

KEY WORDS: Enteromorpha · Macroalgal mats $\cdot$ Flumes $\cdot$ Current velocity $\cdot$ Sediment erosion $\cdot$ Deposition

\section{INTRODUCTION}

Macroalgal blooms of genera such as Enteromorpha, Chaetomorpha and Ulva are widespread on tidal flats of estuaries, lagoons and shallow coastal areas. These blooms are generally associated with elevated nutrient levels, particularly of nitrogen and/or phosphorus (e.g. Venice lagoon, Italy: Sfriso \& Marcomini 1997, 1999, Sfriso et al. 2001; Ythan estuary, Scotland: Raffaelli et al. 1989, 1999; Mondego estuary, Portugal: Martins et al. 2001). By virtue of their simple morphology and broad physiological tolerances, these macroalgal species are able to utilize these elevated nutrient levels and out-compete other seaweeds as well as seagrasses (Raffaelli et al. 1998). The rapid and extensive growth of Enteromorpha and Ulva is therefore commonly used as an indicator of nutrient enrichment and eutrophication of shallow-water systems. The UK Environmental Agency has set a target of restricting coverage of tidal flats by Enteromorpha spp. in the Tees estuary to $<25 \%$ (Environment Agency 1999). However, the causes and consequences of persistent macroalgal blooms appear to be complex and not well understood (Raffaelli et al. 1999). In general, the ecological changes are the result of complex interactions between several physical, chemical and biological factors rather than single factors. In situations where nutrients are not limiting there is no evidence of a simple relationship between nutrient levels in the water column and abundance of Enteromorpha spp. (Pihl et al. 1999). A detailed study of the extensive growth and subsequent decline of the macroalga Ulva rigida in the central part of the Venice lagoon (Sfriso \& Marcomini 1996) indicated that the abatement of nutrient inputs from the mainland appeared to have played a minor role. The presence of macroalgae can influence the chemistry and the microbial activity of the underlying sediment (Raffaelli et al. 1998). In particular, the persistence and 
regeneration of macroalgal blooms is due in part to their ability to control sediment stability, as well as the distribution and residence times of nutrients in the surface sediments, and not vice versa (Sfriso \& Marcomini 1996).

Macroalgal mats can influence the physicalchemical aspects of their environment (e.g. hydro, nutrient, organic and sediment dynamics) and as a result cause major changes to the ecology (e.g. reducing macrofauna, fish and birds). These ecological impacts are particularly serious when the macroalgal mats cover a large proportion ( $>25 \%$ ) of the intertidal area, and may become incorporated into the sediment, decomposing and inducing anoxia (e.g. Venice lagoon: Sfriso \& Marcomini 1997, 1999, Sfriso et al. 2001; Ythan estuary: Raffaelli et al. 1998, 1999).

Various studies have shown that dense macroalgal mats have deleterious effects on macrobenthic communities and their predators such as shorebirds (Raffaelli et al. 1998, 1999, Neira \& Rackemann 1996). For example, in the Venice lagoon macroalgal blooms reduced macrofaunal richness, abundance and biomass by a factor of ca. 3 to 8 times (Sfriso et al. 2001). Macroalgal mats may influence the ecology of shallowwater systems and their intertidal areas via different modes of action:

- physical smothering of the sediment surface and a reduction in water flow over the bed will alter the benthic boundary layer, thus reducing water exchange for suspension feeders and sediment-water exchange (sediment erosion/deposition, nutrient flux);

- reduction in erodability will reduce sediment resuspension and the turbidity of the overlying water column, thus increasing light penetration which will encourage further algal growth (i.e. positive feedback);

- burial of macroalgal biomass during storm events will cause anoxic conditions to develop in the sediments with adverse effects on macrofauna and their predators (i.e. birds and fishes).

At present there is little quantitative information on the effect of macroalgal mats on hydrodynamics and sediment dynamics. Therefore the main objectives of this study were: (1) to quantify the effect of different densities of Enteromorpha intestinalis on the near-bed water flow; (2) to quantify the impact of E. intestinalis density on sediment erodability in response to increasing current velocity; (3) to determine whether $E$. intestinalis enhances sediment deposition.

\section{MATERIALS AND METHODS}

The experimental studies were carried out between June and October 2000. Algal mats of Enteromorpha intestinalis and the underlying sediment were col- lected from the shore between mid-tide and highwater neap-tide levels at Exmouth, SW England (Grid Reference SX992809). At this site, E. intestinalis was attached to small stones (1 to $3 \mathrm{~mm}$ ) and empty shells in the sand. The macroalgal mat covered an area of approx. 1 to 2 ha, which represents about $15 \%$ of the tidal flats at Exmouth (with $\sim 50 \%$ covered by mussel beds towards the main channel).

Sediments $(7 \mathrm{~cm}$ depth) together with attached Enteromorpha intestinalis were collected by means of quadrant cores designed to fit precisely in the Plymouth Marine Laboratory (PML) annular flumes with minimal disturbance (i.e. not significantly different from in situ flume erosion measurements; Widdows et al. 2000). Detailed description of the PML annular flumes and operating procedures are given in Widdows et al. (1998a,b). In summary, the flume represents a smaller, modified version of the design described by Fukada \& Lick (1980). The annular flume is constructed of acrylic material with a $64 \mathrm{~cm}$ (outer) and $44 \mathrm{~cm}$ (inner) diameter, resulting in a $10 \mathrm{~cm}$ channel width with a total bed area of $0.17 \mathrm{~m}^{2}$, a maximum water depth of $38 \mathrm{~cm}$, and a maximum volume of $60 \mathrm{l}$. Current speeds are generated by a rotating annular drive plate (a smooth surface without paddles) driven by a $12 \mathrm{~V}$ motor connected to a controller board and data logger.

During each erosion experiment the sediments in the flumes were subjected to controlled incremental increases in flume drive plate speed from 8 to $75 \mathrm{rpm}$, with each $8 \mathrm{rpm}$ step lasting $20 \mathrm{~min}$. An electromagnetic (EM) current meter (3.2 cm discus head; Valeport Model 800-175) was used to measure vertical profiles of flow velocity (every $1 \mathrm{~cm}$ between 1 and $12 \mathrm{~cm}$ above the bed) at each stepwise increase in drive plate rpm. The concentration of suspended particulate matter (SPM) in the flume was monitored using an optical back-scatter sensor (OBS-3; D \& A Instruments) and the output (V) was recorded every $15 \mathrm{~s}$ by the data logger. The OBS sensor was calibrated against water samples taken for gravimetric analysis, and calibration curves were produced for each experiment. Samples were taken from each flume at the end of each step in the flume speed. The SPM concentrations $\left(\mathrm{mg} \mathrm{l}^{-1}\right)$, mass of sediment eroded $\left(\mathrm{g} \mathrm{m}^{-2}\right)$ and the sediment erosion rate $\left(\mathrm{g} \mathrm{m}^{-2} \mathrm{~s}^{-1}\right)$ were measured every $15 \mathrm{~s}$ throughout the course of the experiment ( $2.5 \mathrm{~h}$ duration). Mean erosion rate was calculated over the first $10 \mathrm{~min}$ of each incremental step.

The annular flumes were used to quantify the effect of different densities (\% cover) of Enteromorpha intestinalis on near-bed water flows and sediment erosion and deposition. On each occasion 'sediment with $E$. intestinalis' was compared with 'sediment without E. intestinalis' (i.e. $0 \%$ cover after careful removal of 
E. intestinalis from sediment). The sampling occasions and the algal densities studied (expressed as \% cover and biomass equivalents) are presented in Table 1. The estimate of \% E. intestinalis cover was based on observations at low tide when the macroalga was lying horizontally on the sediment surface. However, because it has a lower density than seawater, the filaments (approx. $10 \mathrm{~cm}$ in length but ranging from 5 to $15 \mathrm{~cm}$ ) float in the water column when immersed. The area of attachment is relatively small, and therefore most of the sediment is potentially exposed to erosion by the water.

In October 2000 a 'mini-rig' developed at PML was deployed at Exmouth to provide in situ measurements of water depth, current velocity, current direction and SPM. The mini-rig consists of a light 4-legged frame (15 mm copper tubing) which supports an $x-y$ EM current meter (5.5 cm spherical head; Valeport 800), an OBS-1 sensor, and a depth pressure sensor (Druck PDCR 940 0-7 Bar absolute). The EM current and OBS sensors were mounted $10 \mathrm{~cm}$ above the seabed and were connected to a submersible housing containing a $12 \mathrm{~V}$ power supply and microprocessor controllerlogger. The OBS sensor was calibrated against water samples taken for gravimetric analysis from flume experiments with sediment collected from the site. The mini-rig was deployed within the area of Enteromorpha intestinalis growth (10\% cover) and current velocity and SPM were recorded over 2 tidal cycles (26 and 27 October 2000).

Sediment deposition experiments were designed to examine whether Enteromorpha intestinalis significantly enhances sediment deposition and reduces its subsequent resuspension by acting as a sediment trap. These experiments involved high densities of $E$. intestinalis $\left(\sim 60 \%\right.$ cover at $\left.100 \mathrm{~g} \mathrm{~m}^{-2}\right)$ collected in August and September. For each of these experiments, 2 sets of cores were taken from Exmouth: one of sandy substrate with a $60 \%$ cover of E. intestinalis, the other from nearby sediment without an algal mat (i.e. bare sand of similar composition). In the laboratory, the 2 sets of cores of sediment were introduced into the flumes with the E. intestinalis bed run as the 'experimental' and the bare sediment as the 'control'. Equal amounts of fine mud (median diameter $4.6 \mu \mathrm{m}$ ) collected from Halton Quay (Tamar estuary) were added to both flumes with the drive plate at $16 \mathrm{rpm}$. After allowing 2 min for the mixing of the mud throughout the water column, water was sampled for gravimetric analysis $\left(t_{0}\right)$, and the drive plate speed was reduced to and maintained at $8 \mathrm{rpm}$ for the duration of the deposition experiment. This was equivalent to a current speed of $<4 \mathrm{~cm} \mathrm{~s}^{-1}$ and below the critical deposition threshold. The OBS sensor monitored the rapid decline in SPM concentration in both flumes, and water sam-
Table 1. Enteromorpha intestinalis biomass $\left(\mathrm{g} \mathrm{m}^{-2}\right)$ on each sampling occasion from June to October 2000. Data are means for 2 quadrat samples of $0.1 \mathrm{~m}^{2}$ and 1 sample from the flume $\left(0.17 \mathrm{~m}^{2}\right)$. WW: wet weight; DW: dry weight; AFDW: ash-free dry weight

\begin{tabular}{|lrrrrr|}
\hline & \multicolumn{3}{c}{$\begin{array}{c}\text { Erosion } \\
\text { experiments }\end{array}$} & \multicolumn{2}{c|}{$\begin{array}{c}\text { Deposition } \\
\text { experiments }\end{array}$} \\
Date & 5 Jun & 4 Jul & 15 Oct & 2 Oct & 25 Sep \\
\hline Cover (\%) & 60 & 30 & 10 & 60 & 60 \\
WW $\left(\mathrm{g} \mathrm{m}^{-2}\right)$ & 577 & 112 & 62 & 700 & 803 \\
DW $\left(\mathrm{g} \mathrm{m}^{-2}\right)$ & 106 & 22 & 8 & 105 & 92 \\
AFDW $\left(\mathrm{g} \mathrm{m}^{-2}\right)$ & 41 & 9 & 4 & 44 & 59 \\
\hline
\end{tabular}

ples were taken for gravimetric analysis at regular intervals. The day following the sedimentation phase, a resuspension experiment was carried out involving the usual stepwise increase in rpm in an attempt to resuspend the newly deposited fine mud.

After the completion of each experiment, the Enteromorpha intestinalis was removed for measurement of biomass, and the sediment grain size composition was analysed by wet sieving $(n=6)$ and the \% organic matter for each fraction was measured by loss on ignition at $450^{\circ} \mathrm{C}$. The size frequency distribution of the $<63 \mu \mathrm{m}$ fraction of sediment was analysed using a Coulter Counter Multisizer.

\section{RESULTS}

\section{Effect of Enteromorpha intestinalis on near-bed currents}

The presence of Enteromorpha intestinalis exerted a significant drag on the water flow in the flume. Linear relationships between the depth-averaged current velocity $(\bar{U})$ above the bed and the rpm of the flume drive plate were calculated for each E. intestinalis density (Table 2). ANCOVA demonstrated that the density of E. intestinalis had a significant effect on the relationship between $\bar{U}$ and rpm (Table 2). At $60 \%$ algal cover, the currents were significantly lower than at $30 \%$ cover (slope $\mathrm{p}>0.05$; intercept $\mathrm{p}<0.001$ ), and $30 \%$ significantly lower than $10 \%$ algal cover (slope $\mathrm{p}<0.01)$. The lowest cover $(10 \%)$ was also significantly lower than the bare sediment (slope $\mathrm{p}>0.05$; intercept $\mathrm{p}<0.05)$, but there were no significant differences between the 3 flume runs with bare sediments $(\mathrm{p}>$ $0.10)$. The relationships between the electrical power requirements $(\mathrm{mA})$ of the microprocessor-controlled flume motor and the rpm of the drive plate were calculated for all the experimental flume runs. No significant differences were found in these relationships (ANCOVA), indicating that the friction drag induced 
Table 2. Relationship between rpm of flume drive plate and depth-averaged current velocity $\left(\bar{U}_{i} \mathrm{~m} \mathrm{~s}^{-1}\right)$ between 1 and $12 \mathrm{~cm}$ above sediment, with and without Enteromorpha intestinalis at different \% cover. Here and in Table 5 and Fig. 4, percents for bare sediment data indicate sediment after careful removal of the macroalga $(10,30$ or $60 \%$ cover). HG: homogeneous groups, conditions with different letters are significantly different at $\mathrm{p}<0.05$

\begin{tabular}{|lccc|}
\hline Sample & Equation & $\mathrm{r}^{2}$ & HG \\
\hline Bare sediment & & & \\
$10 \%$ & $\bar{U}=0.00522(\mathrm{rpm})$ & 0.95 & $\mathrm{~A}$ \\
$30 \%$ & $\bar{U}=0.00482(\mathrm{rpm})$ & 0.96 & $\mathrm{~A}$ \\
$60 \%$ & $\bar{U}=0.00486(\mathrm{rpm})$ & 0.99 & $\mathrm{~A}$ \\
Sediment + alga & & & \\
$10 \%$ & $\bar{U}=0.00447(\mathrm{rpm})$ & 0.97 & $\mathrm{~B}$ \\
$30 \%$ & $\bar{U}=0.00388(\mathrm{rpm})$ & 0.99 & $\mathrm{C}$ \\
$60 \%$ & $\bar{U}=0.00279(\mathrm{rpm})$ & 0.90 & $\mathrm{D}$ \\
\hline
\end{tabular}

by the presence of $E$. intestinalis did not result in an increase in the power required to generate a given rpm. Consequently, relationships between $\bar{U}$ and rpm for the different $E$. intestinalis densities reflect the drag exerted and its effect on reducing current velocities.
The effect of Enteromorpha intestinalis density on current velocity profiles are shown in Fig. 1. The horizontal shift in the vertical profiles reflects the drag exerted by different densities of $E$. intestinalis relative to the bare sediment $(0 \%$ cover). The decrease in current velocities with increasing density is particularly evident at the lower speeds (16 to $32 \mathrm{rpm}$ ). Above $32 \mathrm{rpm}$ the current velocity profiles become more variable, probably reflecting the increased turbulence and the movements of the E. intestinalis filaments in the water currents. At the majority of speeds there was no evidence of a simple logarithmic profile in the water column profiles. The percent reduction in current velocity caused by E. intestinalis relative to bare sediment is presented in Table 3 . At the highest density $(60 \%$ cover $)$ the percentage reduction in current velocity decreased from $85 \%$ at $8 \mathrm{rpm}$ to a mean reduction of $37 \%$ at speeds between 42 and $67 \mathrm{rpm}$. This decline reflects the changing orientation of the macroalgal filaments from vertical in the water column to horizontal with the flow at higher current velocities. The overall mean reduction in current velocity was $56 \%$ at $60 \%$
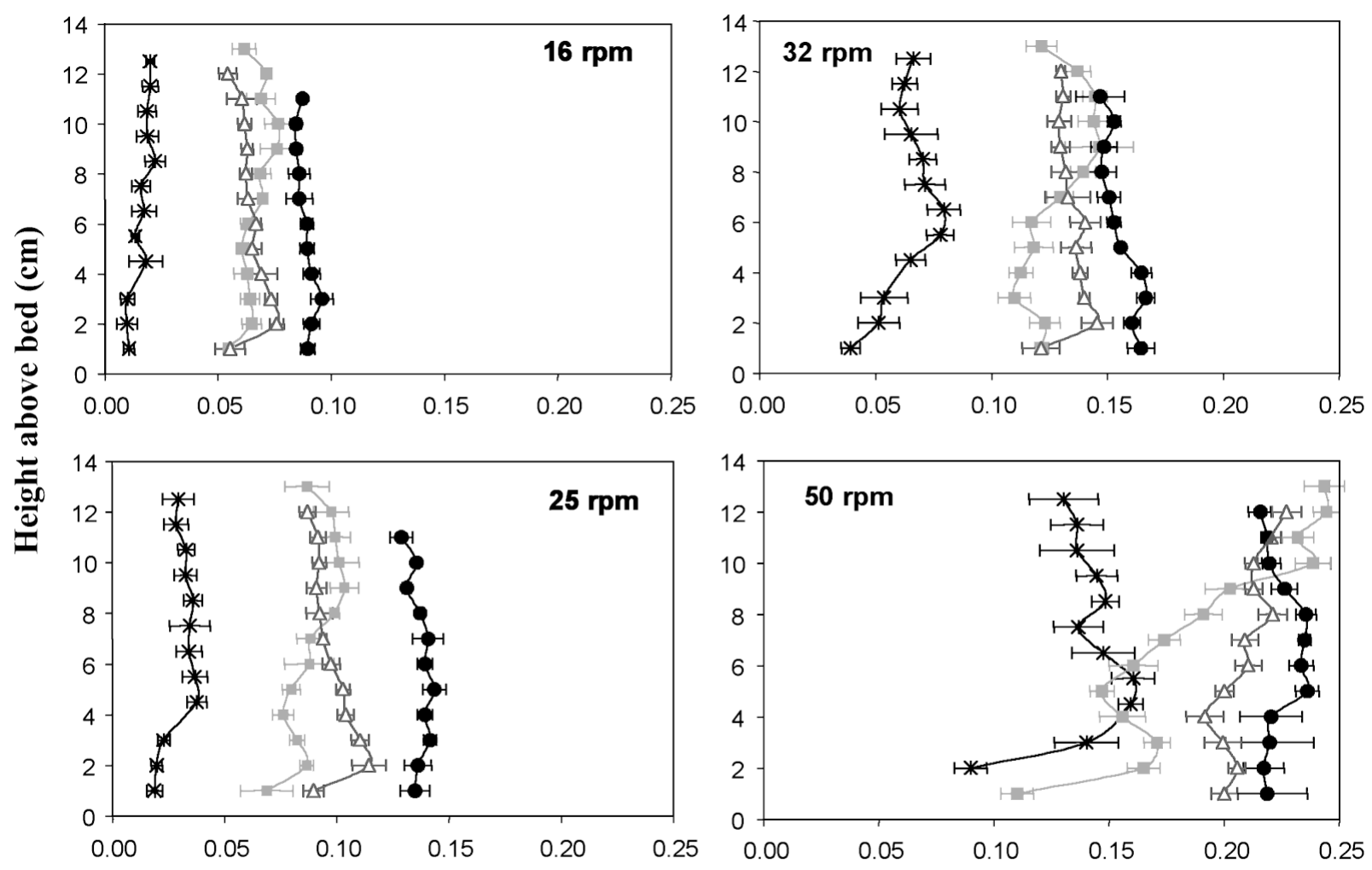

Current velocity $\left(\mathrm{m} \mathrm{s}^{-1}\right)$

* Entero $60 \%-$ Entero $30 \% \multimap-$ Entero $10 \% \multimap-$ Entero $0 \%$

Fig. 1. Enteromorpha intestinalis. Vertical profiles of current velocities (mean $\pm \mathrm{SD}$ ) in relation to 4 flume drive-plate speeds (rpm), showing flow attenuation with increasing densities (\% cover) 
Table 3. Percentage reduction in depth-averaged current velocity at each drive plate speed (rpm) as a function of increasing Enteromorpha intestinalis density (\% cover). Reduction expressed relative to current velocity over bare sand $(0 \%$ cover $)$

\begin{tabular}{|lccc|}
\hline Drive plate (rpm) & $10 \%$ cover & $30 \%$ cover & $60 \%$ cover \\
\hline 8 & 14 & 17 & 85 \\
16 & 27 & 27 & 79 \\
25 & 29 & 32 & 75 \\
33 & 13 & 25 & 58 \\
42 & 15 & 16 & 44 \\
50 & 7 & 20 & 39 \\
58 & 18 & 25 & 28 \\
67 & 18 & 12 & 37 \\
Mean & 18 & 22 & 56 \\
\hline
\end{tabular}

cover, and this declined to 22 and $18 \%$ at 30 and $10 \%$ cover, respectively.

Reliable and accurate estimates of bed-shear stress could not be calculated from the vertical profiles in current velocity due to the complex and turbulent nature of water flow around the Enteromorpha intestinalis and continual movement of the flexible macroalgal filaments in response to the flow.

\section{Effect of Enteromorpha intestinalis on sediment erodability}

The erosion potential of sandy sediments covered with different densities of Enteromorpha intestinalis was measured in terms of critical erosion velocity $\left(\bar{U}_{\text {crit }}\right)$, mass eroded $\left(\mathrm{g} \mathrm{m}^{-2}\right)$ and mean erosion rates $\left(E_{\text {mean }}: \mathrm{g} \mathrm{m}^{-2} \mathrm{~s}^{-1}\right)$ in relation to increasing current velocity (for details see Widdows et al. 1998a,b). The results from the flume experiments not only showed marked differences in the erodability of the sediments as a function of the density or \% cover of E. intestinalis, but also in relation to slight changes in the nature of the bed sediment during the 3 sampling periods between June and October. The sandy sediment at the Exmouth sampling site consisted of well-sorted sand but fractions ranged from shells and pebbles $>11.2 \mathrm{~mm}$ to fine silt $<63 \mu \mathrm{m}$ (Table 4). The most abundant sediment fraction consisted of sand grains between 125 and $250 \mu \mathrm{m}$, which was equivalent to ca. $53 \%$ dry weight of the total sediment material.

Changes in the mass of sediment eroded from the bed with and without Enteromorpha intestinalis cover at 3 different densities and in relation to flume rpm are shown in Fig. 2. There was an increase in the critical erosion threshold $\left(\bar{U}_{\text {crit }}\right)$ and a marked reduction in sediment resuspension with increasing $E$. intestinalis density. However, there was also a seasonal change in the
Table 4 . Sediment grain size (\% of total weight) associated with Enteromorpha intestinalis mats (\% algal cover) on different sampling occasions at Exmouth site from June to October 2000. Data are means of 6 replicates $\pm \mathrm{SD}_{\text {; }}$ determined by wet-sieving

\begin{tabular}{|lrrr|}
\hline Grain size & \multicolumn{1}{c}{$\begin{array}{c}60 \% \text { cover } \\
\text { June }\end{array}$} & \multicolumn{1}{c}{$\begin{array}{c}30 \% \text { cover } \\
\text { July }\end{array}$} & \multicolumn{1}{c|}{$\begin{array}{c}10 \% \text { cover } \\
\text { October }\end{array}$} \\
\hline$>11.2 \mathrm{~mm}$ & $1.57 \pm 0.89$ & $1.15 \pm 1.03$ & $1.06 \pm 0.77$ \\
$2.8-11.2 \mathrm{~mm}$ & $23.32 \pm 3.63$ & $18.60 \pm 3.62$ & $14.57 \pm 7.44$ \\
$1-2.8 \mathrm{~mm}$ & $3.08 \pm 0.53$ & $3.13 \pm 0.78$ & $4.66 \pm 0.76$ \\
$500 \mu \mathrm{m}-1 \mathrm{~mm}$ & $0.93 \pm 0.19$ & $0.82 \pm 0.18$ & $1.29 \pm 0.39$ \\
$250-500 \mu \mathrm{m}$ & $17.97 \pm 10.0$ & $12.05 \pm 2.04$ & $30.95 \pm 8.72$ \\
$125-250 \mu \mathrm{m}$ & $51.62 \pm 8.64$ & $62.29 \pm 5.99$ & $44.39 \pm 9.58$ \\
$63-125 \mu \mathrm{m}$ & $1.06 \pm 0.20$ & $1.53 \pm 0.31$ & $2.28 \pm 0.99$ \\
$<63 \mu \mathrm{m}$ & $0.44 \pm 0.12$ & $0.51 \pm 0.14$ & $0.80 \pm 0.32$ \\
\hline
\end{tabular}

erodability of the bare sandy sediment during the period of experiments from June to October. This may have been due to the accumulation of finer material and relative decline in the stabilising effects of the larger fractions $(>2 \mathrm{~mm})$ during the summer period

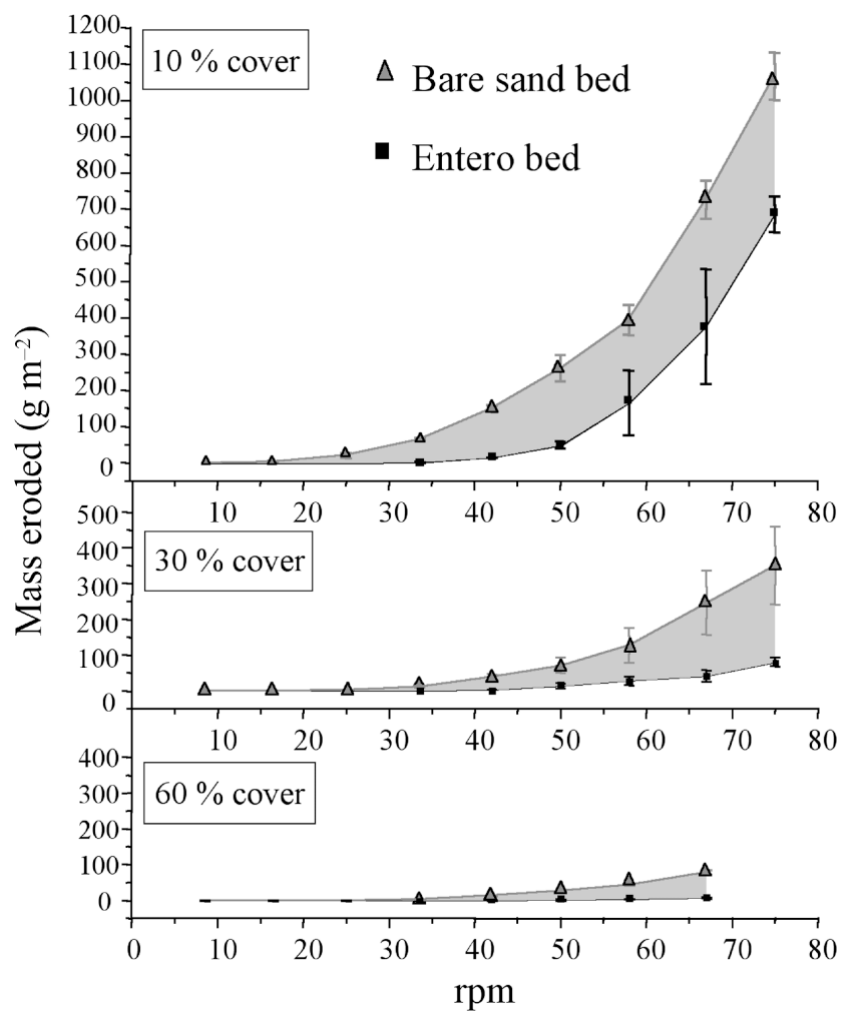

Fig. 2. Enteromorpha intestinalis. Mass of sediment eroded (g $\mathrm{m}^{-2}$ ) in response to stepwise increases in flume speed (rpm). Comparison of sediment erodability with and without $E$. intestinalis at different densities $(10,30$ and $60 \%$ algal cover). Data are means \pm semi range, where $n=2$ replicate flume experiments. Shaded area represents difference in erodability between bare sediment and sediment with alga 
(Table 4). In spite of the changing erodability and nature of the underlying sediment, there was still a relationship between the difference in mass of sediment eroded with and without E. intestinalis (shaded area in Fig. 2) and the density of the macroalgal mat. This has been normalised in Fig. 3, in which the per- cent change in sediment mass eroded for 10, 30 and $60 \%$ algal cover (Bar A of each pair) is expressed relative to $100 \%$ for the bare sediments and at 3 different standardised current velocities (i.e. $0.20,0.25$ and $0.30 \mathrm{~m} \mathrm{~s}^{-1}$ ). However, due to the presence of E. intestinalis and the drag induced by the algal mat, the actual
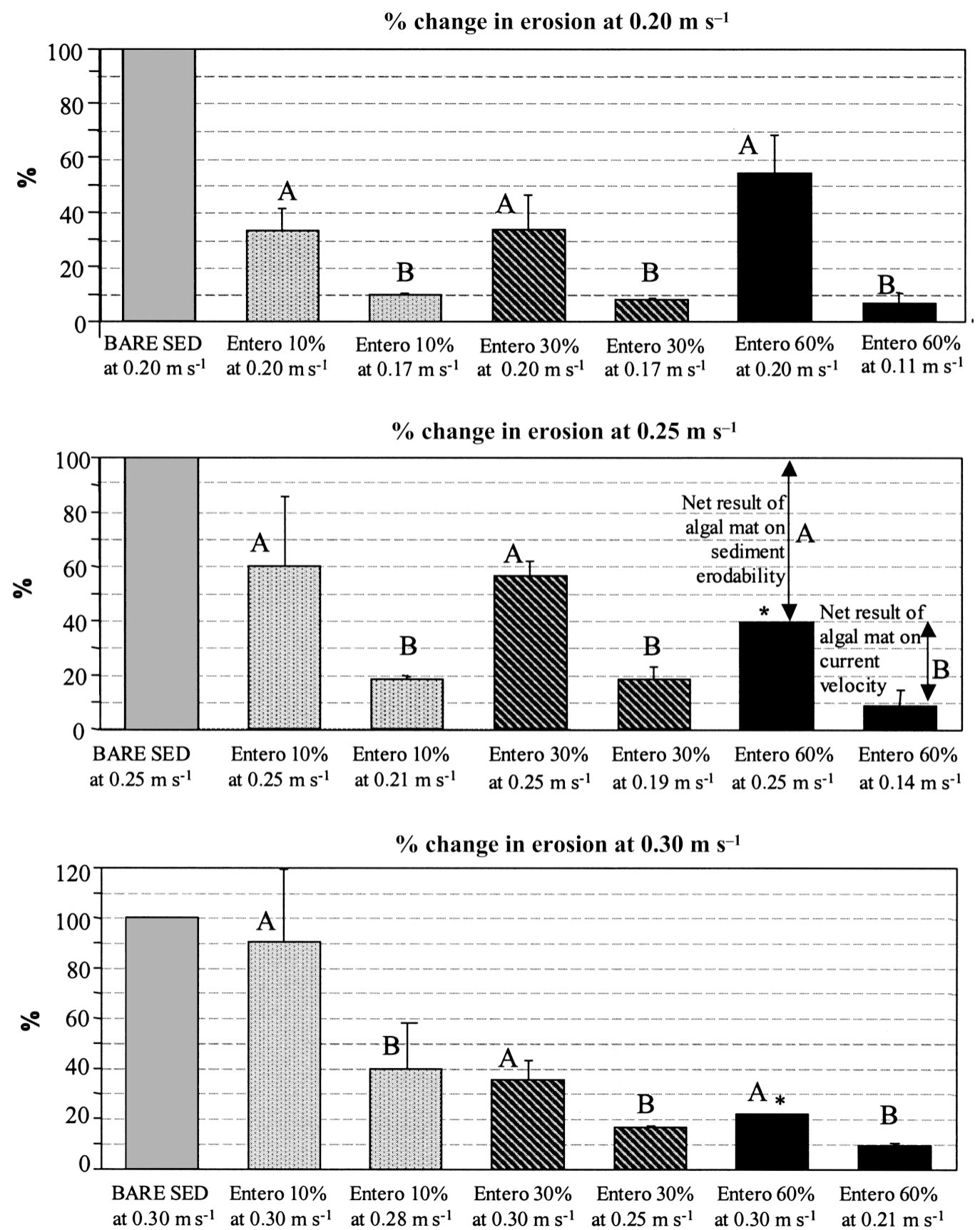

Fig. 3. Enteromorpha intestinalis. Impact of different densities (10, 30 and $60 \%$ cover) on sediment (SED) erosion relative to bare sediment $(100 \%)$. Percentage change in erosion is shown for 3 standardised current velocities $\left(0.20,0.25\right.$ and $0.30 \mathrm{~m} \mathrm{~s}^{-1}$ : A) and at observed (i.e. lower) depth-averaged current velocities induced by each E. intestinalis density (B). Data are mean \pm semi range, where $\mathrm{n}=2$ replicate flume experiments. ${ }^{*}$ Data extrapolated from polynomial regression line describing sediment mass eroded versus current velocity, because of reduction in maximum recorded current velocities at $60 \%$ alga coverage 


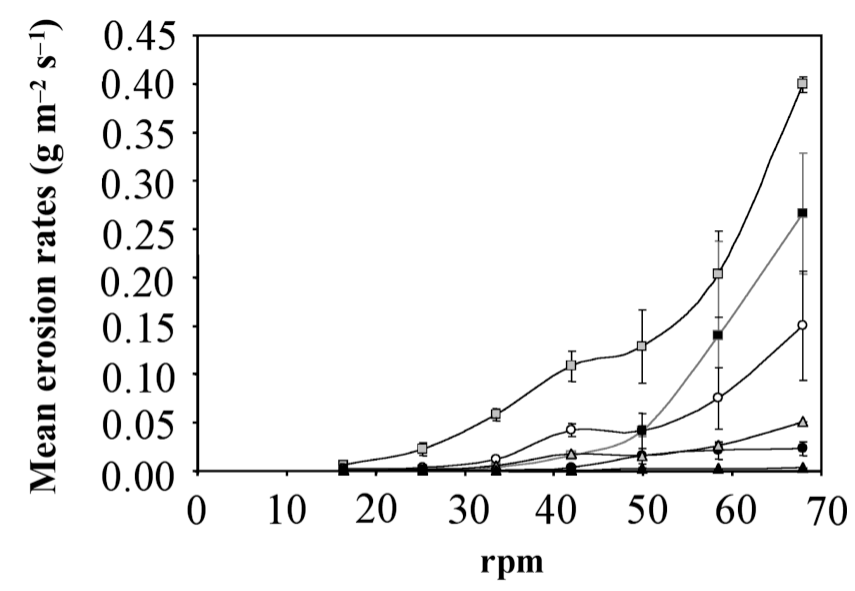

\begin{tabular}{|lll|}
\hline$\square-\operatorname{SED} 10 \%$ & $-0-\operatorname{SED} 30 \%$ & $\smile$ SED 60\% \\
- Entero 10\% & - - Entero 30\% & $\rightarrow$ Entero 60\%
\end{tabular}

Fig. 4. Enteromorpha intestinalis. Impact of different algal densities $(10,30$ and $60 \%$ cover) on mean sediment erosion rate during initial $10 \mathrm{~min}$ at each step in flume drive plate speed (rpm). Data are mean \pm semi range, where $n=2$ replicate flume experiments

mean flow $(\bar{U})$ for a given energy input to the flume (in terms of rpm) was lower than over the bare sand. This reduction in flow further reduced the sediment mass eroded from the bed and this is represented by the second bar (B) in each pair. For example (see Fig. 3), at a standardised flow of $0.25 \mathrm{~m} \mathrm{~s}^{-1}$ the presence of $E$. intestinalis at $60 \%$ cover reduced sediment erosion to $40 \%$ of that recorded for bare sediment. However, the actual current was reduced to $0.14 \mathrm{~m} \mathrm{~s}^{-1}$, and this reduced sediment erosion to $10 \%$ of that recorded for bare sediment at the same rpm. Therefore, the overall impact of $E$. intestinalis is to markedly reduce sediment erosion/resuspension, and the density-dependent nature of this is more apparent at higher current velocities. The mean erosion rates $\left(E_{\text {mean }}\right)$ at different rpm values are presented in Fig. 4 and demonstrate that at the higher speeds the presence of $E$. intestinalis reduces mean erosion rate by $33 \%$ at $10 \%$ cover, $85 \%$ at $30 \%$ cover and $94 \%$ at $60 \%$ cover.

Critical erosion velocities $\left(\bar{U}_{\text {crit }}\right)$ were similar (ranging from 0.19 to $0.22 \mathrm{~m} \mathrm{~s}^{-1}$ ) for the range of Enteromorpha intestinalis densities from 10 to $60 \%$ cover (Table 5). However, with increasing friction drag induced by higher $E$. intestinalis densities, the algal mat is able to resist greater energy input levels (as reflected in the rpm values in Table 5) before the critical erosion threshold is reached. For example, at 10 and $30 \%$ E. intestinalis coverage, the critical erosion threshold occurs at drive plate speeds that are $17 \mathrm{rpm}$ higher than the erosion thresholds for bare sand.

The $\bar{U}_{\text {crit }}$ for the bare sandy sediment ( $0 \%$ cover) was $0.2 \mathrm{~m} \mathrm{~s}^{-1}$ in June, and this declined to $0.15 \mathrm{~m} \mathrm{~s}^{-1}$ in July and $0.11 \mathrm{~m} \mathrm{~s}^{-1}$ in October (Table 5). The sandy sediment in the summer was probably more stable due to the higher proportion of larger granules and pebbles (i.e. $>2 \mathrm{~mm})$ and less fine-grain material $(<0.5 \mathrm{~mm})$. Erosion of the generally coarser sediment in June was more in the form of rolling, saltation and near-bed transport. In the autumn, however, the sediment with $10 \%$ macroalgal cover resuspended more readily due to the higher proportion of smaller particles (Table 4). In the experiment in October with $E$. intestinalis at $10 \%$ cover, the difference in the mass eroded between the 2 replicate flumes, particularly at higher currents $\left(>0.25 \mathrm{~m} \mathrm{~s}^{-1}\right)$, was greater than usual. The lower sediment erodability in 1 flume was probably due to the presence of previously buried macroalgal material within the top few centimetres of the sandy sediment (as a result of storms in late August), thus increasing its binding and stability.

During the flume experiments, sand ripples were observed at different depth-averaged current velocities for each Enteromorpha intestinalis density, but there was no evidence of significant detachment from the bed. At $0 \%$ cover, sediment ripples appeared at
Table 5. Critical erosion velocity $\left(\bar{U}_{\text {criti }} \mathrm{m} \mathrm{s}^{-1}\right)$ based on threshold of $10 \mathrm{~g} \mathrm{~m}^{-2}(\sim 50 \mathrm{mg}$ $\mathrm{l}^{-1}$ ) for each Enteromorpha intestinalis density/sediment condition. Equation describing mass eroded, $\mathrm{ME}\left(\mathrm{g} \mathrm{m}^{-2}\right)$ versus current velocity, $\bar{U}\left(\mathrm{~m} \mathrm{~s}^{-1}\right)$; Mean $\bar{U}_{\text {crit }}$ : mean critical erosion velocity $( \pm$ semi-range, $\mathrm{n}=2$ ); rpm: drive plate speed

\begin{tabular}{|lcccc|}
\hline $\begin{array}{l}\text { Experimental } \\
\text { condition }\end{array}$ & Equation & $\mathrm{r}^{2}$ & $\begin{array}{c}\text { Mean } \bar{U}_{\text {crit }} \\
\left(\mathrm{m} \mathrm{s}^{-1}\right)\end{array}$ & $\mathrm{rpm}$ \\
\hline $\begin{array}{l}\text { Bare sediment } \\
\text { Oct, } 10 \%\end{array}$ & $\mathrm{ME}=0.3408 \mathrm{e}^{28.4883 \bar{U}}$ & 0.99 & $0.112 \pm 0.007$ & 25 \\
& $\mathrm{ME}=0.7091 \mathrm{e}^{25.1479 \bar{U}}$ & 0.96 & & \\
July, 30\% & $\mathrm{ME}=0.6628 \mathrm{e}^{17.7064 \bar{U}}$ & 0.91 & $0.153 \pm 0.0001$ & 33 \\
& $\mathrm{ME}=0.2241 \mathrm{e}^{24.7569 \bar{U}}$ & 0.97 & & \\
June, 60\% & $\mathrm{ME}=0.1803 \mathrm{e}^{20.4495 \bar{U}}$ & 0.94 & $0.202 \pm 0.006$ & 42 \\
& $\mathrm{ME}=0.0848 \mathrm{e}^{22.8836 \bar{U}}$ & 0.94 & & \\
Sediment +alga & & & & \\
$10 \%$ & $\mathrm{ME}=0.0340 \mathrm{e}^{30.7173 \bar{U}}$ & 0.96 & $0.185 \pm 0.0001$ & 42 \\
$30 \%$ & $\mathrm{ME}=0.0023 \mathrm{e}^{45.3518 \bar{U}}$ & 0.99 & & \\
& $\mathrm{ME}=0.0881 \mathrm{e}^{22.3032 \bar{U}}$ & 0.98 & $0.198 \pm 0.014$ & 50 \\
$60 \%$ & $\mathrm{ME}=0.0587 \mathrm{e}^{27.8536 \bar{U}}$ & 0.86 & & \\
& $\mathrm{ME}=0.0530 \mathrm{e}^{23.8586 \bar{U}}$ & 0.94 & $0.219 \pm 0.001$ & 67 \\
& $\mathrm{ME}=0.3553 \mathrm{e}^{15.3358 \bar{U}}$ & 0.97 & & \\
\hline
\end{tabular}



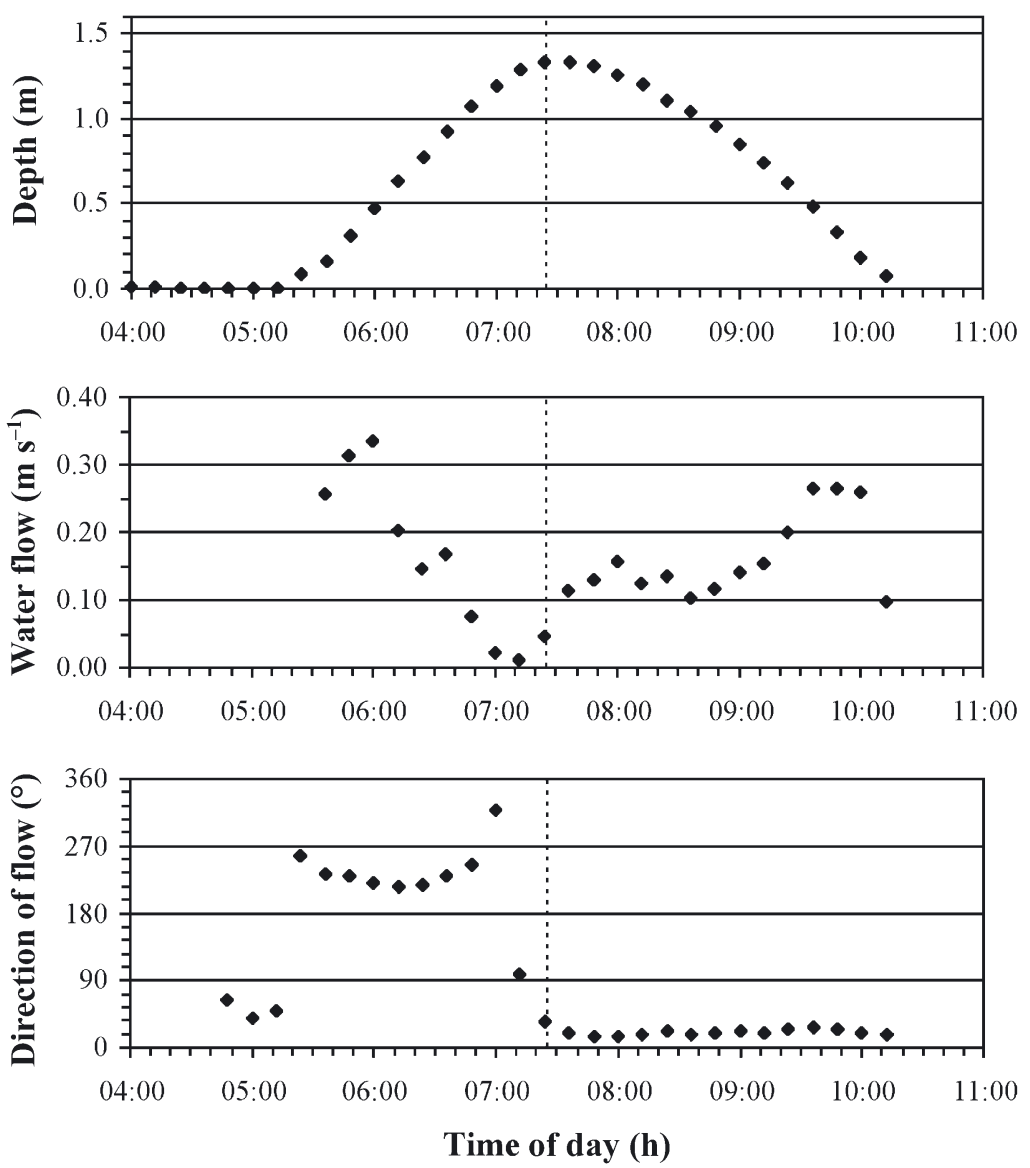

Fig. 5. Recorded current velocities, their direction and water depth over a tidal cycle at the collection site at Exmouth. Data obtained from deployment of mini-rig during spring tides on 27 October 2000

$0.20 \mathrm{~m} \mathrm{~s}^{-1}$ (42 rpm) and they migrated at $0.29 \mathrm{~m} \mathrm{~s}^{-1}$ (58 rpm). At $10 \%$ cover, sediment ripples formed at $0.22 \mathrm{~m} \mathrm{~s}^{-1}(50 \mathrm{rpm})$ and they started to migrate at $0.26 \mathrm{~m} \mathrm{~s}^{-1}(58 \mathrm{rpm})$, with some $E$. intestinalis becoming detached. At $30 \%$ cover, sediment ripples developed at $0.26 \mathrm{~m} \mathrm{~s}^{-1}(67 \mathrm{rpm})$, but there was no observed migration. At $60 \%$ cover, no ripple formations were observed. When current velocities were $>0.2 \mathrm{~m} \mathrm{~s}^{-1}, E$. intestinalis filaments were largely horizontal in the flow with the upper edge of streamlined algae ca. $5 \mathrm{~cm}$ above the bed. Consequently, when the macroalgal density was high (60\% cover), there was little sediment erosion because the bed was largely covered and protected by the algal filaments and the near-bed currents were reduced by the friction drag.

The range of current velocities used in flume experiments (ca. 0.01 to $0.35 \mathrm{~m}$ $\mathrm{s}^{-1}$ ) were consistent with currents recorded at the Exmouth sampling site over 2 spring tidal cycles on 26 and 27 October 2000. On 26 October, the maximum water flow was $0.26 \mathrm{~m} \mathrm{~s}^{-1}$ with a duration of $30 \mathrm{~min}$. On the following day (27 October) conditions were windy $\left(\sim 4 \mathrm{~m} \mathrm{~s}^{-1}\right.$ from the south), and for ca. 30 min during flood tide the water flows over the Enteromorpha intestinalis mats were higher (i.e. 0.30 to $0.34 \mathrm{~m} \mathrm{~s}^{-1}$ : Fig. 5). Unfortunately, no SPM data were obtained from this field deployment because some detached E. intestinalis vegatation wrapped itself around the OBS sensor.

\section{Effect of Enteromorpha intestinalis on sedimentation of fine mud}

The mean SPM concentration in the flumes at the beginning of the deposition experiments was $103 \pm 6 \mathrm{mg} \mathrm{l}^{-1}$, and in each experiment $(n=2)$ there was a rapid decline in SPM; however this was not a simple exponential function with a single half-time (semi-log plot: Fig. 6). The initial phase of sedimentation (0 to $30 \mathrm{~min}$ ) was characterised by fast deposition rates (mean \pm semi-range) of $1.33 \pm 0.08$ and $0.90 \pm 0.19 \mathrm{~g} \mathrm{~m}^{-2} \mathrm{~min}^{-1}$ (half-times of $13.5 \pm 0.8$ and $21 \pm 4 \mathrm{~min}$ ) in experiments with and without Enteromorpha intestinalis respectively (Table 6) for 1 of 2 replicate experiments. These higher rates of deposition were presumably due to the aggregation of particles into flocs.

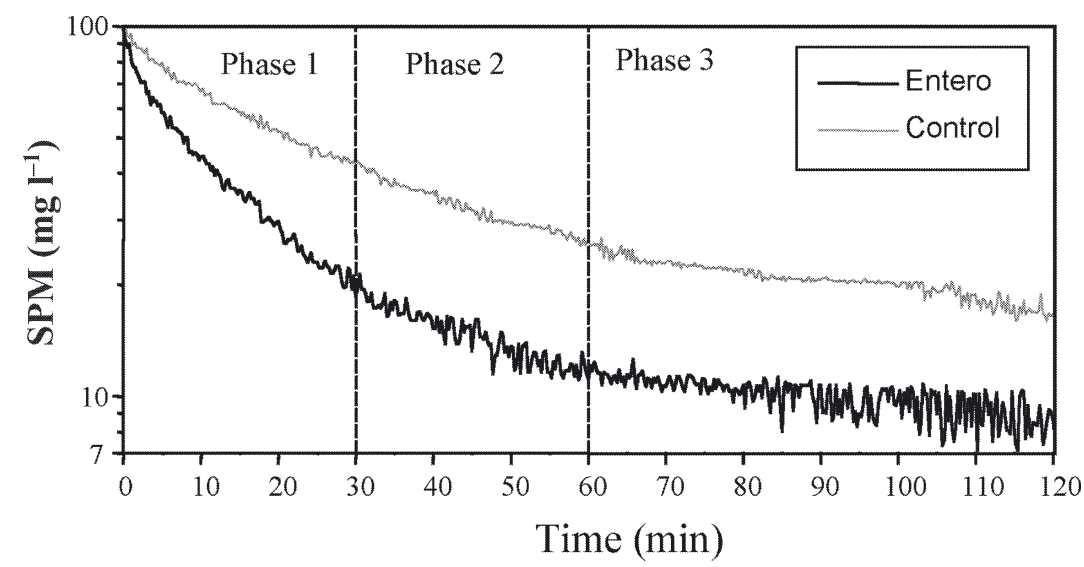

Fig. 6. Decline in concentration of suspended particulate matter (SPM), reflecting sediment deposition over period of $120 \mathrm{~min}$ in presence ( $60 \%$ cover) and absence of Enteromorpha intestinalis. First of 2 replicate flume-deposition experiments. Curves divided into 3 phases, each described by different exponential equations (Table 6 ) 
During the period between 30 and 60 min there was a slower rate of deposition $\left(0.10 \pm 0.01\right.$ and $0.15 \pm 0.01 \mathrm{~g} \mathrm{~m}^{-2}$ $\mathrm{min}^{-1}$ ) with a half-time of $41 \pm 1$ and $45 \pm 3$ min for the sediment with and without E. intestinalis respectively. After $60 \mathrm{~min}$ the deposition times were very slow $\left(<0.04 \mathrm{~g} \mathrm{~m}^{-2} \mathrm{~min}^{-1}\right)$ with halftimes of $>100 \mathrm{~min}$.

Flume deposition experiments not only showed that the presence of the Enteromorpha intestinalis mat significantly increased the flux of SPM from the water column to the bed, particularly during the initial $30 \mathrm{~min}$, but that it also reduced the potential for resuspension of newly deposited fine mud. Erosion experiments carried out after deposition demonstrated that it was only possible to begin to resuspend this fine material from the bed sediment at high drive plate speeds (above $50 \mathrm{rpm}$ or $>0.23 \mathrm{~m} \mathrm{~s}^{-1}$ ). In contrast, the fine material deposited on bare sand was more easily resuspended and SPM concentrations in the water column started to increase at $25 \mathrm{rpm}$ (equivalent to $0.13 \mathrm{~m}$ $\mathrm{s}^{-1}$ ). The presence of an E. intestinalis mat (e.g. $60 \%$ cover) therefore means that it requires twice as much energy (rpm) to overcome the friction drag induced by the macroalgal mat.

\section{DISCUSSION}

The complex interactions between hydrodynamics, sediment dynamics and macrophytes have been conceptualised, but very few studies have quantified the relationships (Madsen et al. 2001). In the present study, the density-dependent effects of a dominant and widespread intertidal macroalgae (Enteromorpha intestinalis) on near-bed hydrodynamics and sediment dynamics have been quantified. There was a reduction in current velocity in the flume with increasing $E$. intestinalis biomass ( $55 \%$ reduction at $60 \%$ cover) due to friction drag. The net result of the physical protection of the bed by E. intestinalis together with a significant reduction in current velocity was a marked reduction in sediment erosion $(90 \%$ decline at $60 \%$ cover). At this coverage, E. intestinalis also enhanced sediment deposition by nearly $50 \%$, particularly during the early period (30 min) of slack water at high tide.

The present study has shown that a macroalgal mat of Enteromorpha intestinalis will influence the hydrodynamics over a tidal flat by reducing the near-bed current velocity. The reduction in current velocity increased with increasing percentage cover of the alga, and the percent decline in current velocity over the E. intestinalis bed relative to bare sediment was greatest at lower current speeds (Table 3). This was primarily due to the orientation of the algal filaments in the water column. At low water-flows the buoyant filaments were generally vertical, but as current velocities increased $\left(>0.2 \mathrm{~m} \mathrm{~s}^{-1}\right)$ the flexible filaments adopted a near horizontal position closer to the bed ( $\sim \mathrm{cm}$ above the bed). At high densities the intermesh of algal filaments formed a dense layer that prevented eddies and currents from penetrating that layer. At these higher densities there was a 'skimming flow' (Vogel 1994) over the alga mat (Fig. 1: $50 \mathrm{rpm}$ ).

Similar flow-attenuation affects have been recorded for seagrasses, highlighting their ability to dissipate tidal and wave energy. Flume studies by Fonseca \& Fisher (1986) compared canopy friction and sediment movement in relation to different densities of 4 seagrass species. They showed that the strap-bladed species (Thalassia testudinum) created greatest canopy friction and the greatest protection of the sediment surface. Gambi et al. (1990) also recorded a reduction in flow within a seagrass canopy (2 to 10 times slower than upstream) that was dependent on seagrass density, but showed increased flow (i.e. skimming flow) above the vegetation. Consequently, shear velocities above the canopy were 2 - to 11-fold higher than at an equivalent height outside the vegetated area. In a field study, Koch \& Gust (1999) recorded skimming flow over meadows of the seagrass $T$. testudinum and a marked reduction (50 to $90 \%$ ) in currents within the seagrass beds.

There were comparable reductions in near-bed flow in the present study with Enteromorpha intestinalis (Table 3). The percent reduction in depth averaged current velocity with increasing density of the alga reflected the increase in friction drag. At high densities ( $60 \%$ cover) and at low current speeds (i.e. $<0.15 \mathrm{~m} \mathrm{~s}^{-1}$ over bare sediment), the near-bed currents were markedly reduced and were 15 to $25 \%$ of the currents 
over non-vegetated sediments (Fig. 1). As the currents increased (i.e. $>0.15 \mathrm{~m} \mathrm{~s}^{-1}$ ), the flexible E. intestinalis filaments became streamlined and more horizontal in the flow, thus reducing the drag, and the currents were $\sim 65 \%$ of the water flow, over bare sediments. Because of the flexibility of $E$. intestinalis and its streamlining in response to increasing water flow, we were unable to determine log profiles of current velocity and thus estimate shear stress within or above the vegetation. The form of the vertical profiles in the majority of studies involving macrophytes is usually complex and deviates from the logarithmic profile in free-stream flows (e.g. Gambi et al. 1990, Pethick \& Leggett 1990, Leonard \& Luther 1995, Shi et al. 1995). In flume studies using nylon filaments to simulate vegetation, Ikeda et al. (1996) showed the complexity of flow over flexible 'water plants' with the presence of 3-dimensional organised vortices.

The present results are consistent with other studies that have examined the density-dependent impact of submerged macrophytes on water movement (reviewed by Madsen et al. 2001). The findings support the conclusion reached by Ward et al. (1984), Koch (1999), and van Keulen (1997), based on fieldwork, that macrophyte density is an important factor determining current velocity reduction and turbulence generation. This is in contrast to the flume studies of Fonseca \& Fisher (1986) and Gambi et al. (1990), which suggest that macrophyte density is not an important factor, particularly with the development of skimming flow. However, these latter studies were conducted over a narrow range $(\sim 2$-fold) at relatively high densities. Clearly, the present findings over a wide range of Enteromorpha intestinalis densities $(\sim 10$-fold in macroalgal ash-free dry wt) would indicate that macrophyte density is a critical factor and should be included in new mathematical models of the impact of biota on hydrodynamics and sediment dynamics (e.g. Wood \& Widdows 2002).

When water flows over vegetation, high shear stresses are transferred from the sediment surface to the top of the vegetation, thus reducing the potential for sediment resuspension (Madsen et al. 2001). However, very few studies have measured sediment erosion and deposition in relation to changes in near-bed currents and macrophyte densities. Fonseca \& Fisher (1986) measured the onset of sediment movement and deposition (entrainment function) in relation to changes in flow and seagrass density, and concluded that the development of skimming flow virtually eliminates density-dependent effects. In contrast, the present study shows that over a wide range of macrophyte density (10-fold) there is an influence on both flow and sediment erodability (Fig. 3). At the Exmouth field site, maximum flows $\left(>0.20 \mathrm{~m} \mathrm{~s}^{-1}\right)$ occurred for
$30 \mathrm{~min}$ at the beginning of the flood and the end of the ebb tide in shallow water $(<0.5 \mathrm{~m}$ depth: Fig. 5). At these flows the Enteromorpha intestinalis filaments would be streamlined with the flow, thus protecting the bed from significant erosion, and high shear stresses would be transferred to the water above the vegetation.

The observed effects of Enteromorpha intestinalis on flow and sediment stability can have important ecological consequences, not only for benthic-pelagic fluxes of sediments and nutrients, but also for the persistence of E. intestinalis algal mats as well as the biomass and diversity of macrobenthic communities and their predators. The growth and persistence of this nuisance macroalgae in estuaries, lagoons and embayments may be due in part to the positive feedback that it induces. Enteromorpha will lower near-bed current flow, thus reducing sediment resuspension and turbidity, which in turn increases light penetration, and this will enhance its growth potential.

In shallow coastal areas where nutrients are generally available in excess, Pihl et al. (1999) found that Enteromorpha intestinalis distribution patterns were related to hydrographic conditions rather than local nutrient levels. They observed a significant negative relationship between algal abundance and physical factors such as wind, wave exposure and water exchange. Increased wave exposure and current velocities are important factors in controlling algal biomass because they can disperse nutrients, maintain a mobile sediment and prevent attachment of macoalgae to the substrata. The present flume studies have shown that E. intestinalis attached to non-cohesive sandy substrate is vulnerable to erosion and disturbance when near-bed current velocities are $>0.25 \mathrm{~m} \mathrm{~s}^{-1}$ (at least at the lowest density). However, in more recent field studies we have found that E. intestinalis can persist, albeit with some shedding of filaments, in environments with firm substrates (consolidated London clays) and with near-bed flows (depth $=10 \mathrm{~cm}$ ) of up to $0.7 \mathrm{~m}$ $\mathrm{s}^{-1}$ (J. Widdows unpubl. data). In the eutrophic Mondego estuary in Portugal, Martins et al. (2001) showed that Enteromorpha spp. biomass is controlled by hydrodynamics, the tidal amplitude and the input of freshwater, which in turn has significant impact on salinity, N:P ratio and turbidity of the water column. However, their recorded maximum currents of $1.4 \mathrm{~m}$ $\mathrm{s}^{-1}$ were at $1 \mathrm{~m}$ depth and in mid-channel, and so are not directly comparable to the near-bed current velocities measured in the present field and flume studies.

The presence of macroalgal mats can have a direct and indirect (via influences on water flow, sediment stability and anoxic sediments) impact on the biomass and diversity of macrobenthic communities and their predators (birds and fishes). The reduction in currents 
associated with macrophytes has long been recognised as having an adverse effect on filter-feeding bivalves (Kirby-Smith 1972). The amphipod Corophium volutator is generally a species dramatically reduced by the presence of macroalgal mats, but at high algal biomass there is also a decline in important polychaetes such as Nereis diversicolor and the spionids Pygospio elegans and Streblospio shrubsolli (Nicholls et al. 1981, Raffaelli et al. 1998, 1999). Hull (1987) and Raffaelli et al. (1991) suggested that movement of Enteromorpha spp. filaments by the water currents may physically interfere with the normal surface deposit-feeding behaviour of these species. In contrast, species such as Capitella capitata, and the grazer Hydrobia ulvae have been found to increase in abundance and biomass in algae-covered areas.

The proliferation of filamentous algae and related structural changes to the habitat are likely to cause considerable alterations in predator-prey relationships in shallow waters. Experimental studies have shown that an increasing percent cover of Enteromorpha intestinalis in sandy embayments has a negative effect on the foraging success of fish predators (Isaksson et al. 1994). In addition, shorebirds such as the dunlin Calidris alpina avoid areas covered by macroalgae in summer, whereas in winter curlew Numenius arquata, redshank Tringa totanus and grey plover Pluvialis squatarola avoid areas that carried a high biomass of $E$. intestinalis the previous summer (Nicholls et al. 1981). These observations suggests that the algal mats per se, or the associated high levels of hydrogen sulphide in the sediment, and/or the depletion of macrofauna, act as a deterrent to waders.

In conclusion, this study has shown that Enteromorpha intestinalis has a marked influence on water flow over the bed and hence the flux of particulate material across the sediment-water interface. The impact of $E$. intestinalis on its physical environment is dependent on the density of the macroalgal mats. Increasing abundance and surface coverage provides greater physical protection of the sediment surface and increases friction drag. This results in lower near-bed currents, reducing the potential for sediment erosion and enhancing sediment deposition. As a consequence of these processes, E. intestinalis at higher densities can have important ecological effects on the benthic community and their predators (birds and fishes). Improved understanding and quantification of the complex interactions between hydrodynamics, sediment dynamics and macrophytes will improve parameterisation of models of the morphology and dynamics of intertidal estuarine sediments.

Acknowledgements. We thank the University of Catania and the University of Palermo for supporting this work through a postgraduate studentship and a Leonardo da Vinci grant to C.R. This work was part funded by the DEFRA (contract no. AE0259) and NERC (ECoH core strategic research programme).

\section{LITERATURE CITED}

Environment Agency (1999) Tees estuary present and future: State of Tees estuary environment, and strategy into the millennium. Environment Agency, Leeds

Fonseca MS, Fisher JS (1986) A comparison of canopy friction and sediment movement between four species of seagrass with reference to their ecology and restoration. Mar Ecol Prog Ser 29:15-22

Fukada MK, Lick W (1980) The entrainment of cohesive sediment in freshwater. J Geophys Res 85:2813-2824

Gambi MC, Nowell ARM, Jumars PA (1990) Flume observations on flow dynamics in Zostera marina (eelgrass) beds. Mar Ecol Prog Ser 61:159-169

Hull SC (1987) Macroalgal mats and species abundance-a field experiment. Estuar Coast Shelf Sci 25:519-532

Ikeda S, Member ASCE, Kanazawa M (1996) Threedimensional organized vortices above flexible water plants. J Hydraul Eng 122:634-640

Isaksson I, Pihl L, Vanmontfrans J (1994) Eutrophicationrelated changes in macrovegetation and foraging of young cod (Gadus morhua L.) - a mesocosm experiment. J Exp Mar Biol Ecol 177:203-217

Kirby-Smith WW (1972) Growth of the bay scallops, the influence of experimental water currents. J Exp Mar Biol Ecol 8:7-18

Koch EW (1999) Sediment resuspension in a shallow Thalassia testudinum banks ex König bed. Aquat Bot 65:269-280

Koch EW, Gust G (1999) Water flow in tide- and wavedominated beds of the seagrass Thalassia testudinum. Mar Ecol Prog Ser 184:63-72

Leonard LA, Luther ME (1995) Flow hydrodynamics in tidal marsh canopies. Limnol Oceanogr 40:1474-1484

Madsen JD, Chambers PA, James WF, Koch EW, Westlake DF (2001) The interaction between water movement, sediment dynamics and submersed macrophytes. Hydrobiologia 444:71-84

Martins I, Pardal MA, Lillebo AI, Flindt MR, Marques JC (2001) Hydrodynamics as a major factor controlling the occurrence of green macroalgal blooms in a eutrophic estuary: a case study on the influence of precipitation and river management. Estuar Coast Shelf Sci 52:165-177

Neira C, Rackemann M (1996) Black spots produced by buried macroalgae in intertidal sandy sediments of the Wadden Sea: effects on meiobenthos. J Sea Res 36: 153-170

Nicholls DJ, Tubbs CR, Haynes FN (1981) The effect of green algal mats on intertidal macrobenthic communities and their predators. Kiel Meeresforsch 5:511-520

Pethick J, Leggett D (1990) Boundary layers under salt marsh vegetation development in tidal currents. In: Thornes JB (ed) Vegetation and erosion. John Wiley \& Sons, London, p 113-124

Pihl L, Svenson A, Moksnes PO, Wennhage H (1999) Distribution of green algal mats throughout shallow soft bottoms of the Swedish Skagerrak archipelago in relation to nutrient sources and wave exposure. J Sea Res 41:281-294

Raffaelli D, Hull S, Milne H (1989) Long-term changes in nutrients, weed mats and shorebirds in an estuarine system. Cah Biol Mar 30:259-270

Raffaelli DG, Lima J, Hull S, Pont S (1991) Interactions 
between invertebrates and macroalgal mats on estuarine mudflats. J Mar Biol Assoc UK 71:899-908

Raffaelli D, Raven JA, Poole LJ (1998) Ecological impact of green macroalgal blooms. Oceanogr Mar Biol Annu Rev 36:97-125

Raffaelli D, Balls P, Way S, Patterson IJ, Hohmann S, Corp N (1999) Major long-term changes in the ecology of the Ythan estuary, Aberdeenshire, Scotland; how important are physical factors? Aquat Conserv 9:219-236

Sfriso A, Marcomini A (1996) Decline of Ulva growth in the lagoon of Venice. Bioresour Technol 58:299-307

Sfriso A, Marcomini A (1997) Macrophyte production in a shallow coastal lagoon. 1. Coupling with chemico-physical parameters and nutrient concentrations in waters. Mar Environ Res 44:351-375

Sfriso A, Marcomini A (1999) Macrophyte production in a shallow coastal lagoon. Part II. Coupling with sediment, SPM and tissue carbon, nitrogen and phosphorus concentrations. Mar Environ Res 47:285-309

Sfriso A, Birkemeyer T, Ghetti PF (2001) Benthic macrofauna changes in areas of Venice lagoon populated by seagrasses or seaweeds. Mar Environ Res 52:323-349

Shi Z, Pethick JS, Pye K (1995) Flow structure in and above the various heights of a saltmarsh canopy: a laboratory flume study. J Coast Res 11:1204-1209

Editorial responsibility: Otto Kinne (Editor),

Oldendorf/Luhe, Germany van Keulen M (1997) Water flow in seagrass ecosystems. PhD thesis, Murdoch University, Perth, Western Australia Vogel S (1994) Life in moving fluids. Princeton University Press, Princeton, NJ

Ward LG, Kemp WM, Boynton WR (1984) The influence of waves and seagrass communities on suspended particulates in an estuarine embayment. Mar Geol 59:85-103

Widdows J, Brinsley MD, Bowley N, Barrett C (1998a) A benthic annular flume for in situ measurement of suspension feeding/biodeposition rates and erosion potential of intertidal cohesive sediments. Estuar Coast Shelf Sci 46:27-38

Widdows J, Brinsley MD, Elliott M (1998b) Use of in situ flume to quantify particle flux (deposition rate and sediment erosion) for an intertidal mudflat in relation to changes in current velocity and benthic macrofauna. In: Black KS, Paterson DM, Cramp A (eds) Sedimentary processes in the intertidal zone, Vol 139. Geological Society London, London, p 85-97

Widdows J, Brinsley MD, Salkeld PN, Lucas CH (2000) Influence of biota on spatial and temporal variation in sediment erodability and material flux on a tidal flat (Westerschelde, The Netherlands) Mar Ecol Prog Ser 194:23-37

Wood RG, Widdows J (2002) A model of sediment transport over an intertidal transect, comparing the influences of biological and physical factors. Limnol Oceanogr 47:848-855

Submitted: March 12, 2002; Accepted: February 6, 2003

Proofs received from author(s): June 18, 2003 